\title{
Linguistic Equality in International Law: Miscommunication in the Gulf Crisis
}

\author{
Christopher B. Kuner*
}

\section{INTRODUCTION}

Despite the fact that language is "the main vehicle of communication between nations"' and "serves as either the bridge or the barrier upon which the organized relations between States are built,"'2 little attention has been devoted to its place in international law. ${ }^{3}$ However, evidence of a communications gap in the recent Persian Gulf Crisis, fueled particularly by profound linguistic and cultural differences ${ }^{4}$

* Of the New York and Illinois Bars. J.D., Notre Dame Law School; LL.M. in International Legal Studies, New York University School of Law.

The author wishes to express his gratitude to Professor Gamal M. Badr for reviewing an earlier draft of this article.

1. M. Tabory, Multilingualism in International Law and Institutions 1 (1980) [hereinafter TABORY]. In this article "language" is used in the sense of words, whether spoken or written. It is of course true that in diplomacy actions may also be viewed as a form of language. See S. Gaselee, The Language of Diplomacy 9 (1939).

2. TABORY, supra note 1 , at 1 .

3. One exception is the interpretation of multilingual treaties. See, e.g., M. Hilf, Die Auslegung mehrsprachiger Verträge (1973) [hereinafter Hilf]; see also TABORY, supra note 1, at 168-226; Kuner, The Interpretation of Multilingual Treaties: Comparison of Texts versus the Presumption of Similar Meaning, 40 INT'L \& CoMP. L.Q. 953 (1991).

It must be emphasized that the use of language in international relations is governed by international law, not just by diplomatic practice. HiLf, supra at $27 \mathrm{n}$. 104; $2 \mathrm{~A}$. Ostrower, Language, Law, and Diplomacy 769-774 (1965) [hereinafter Ostrower]. Diplomatic practice, as distinguished from international law, reflects "the forms of diplomacy as it is practiced, the accepted form of intercourse between states within diplomatic protocol, rules of etiquette, and deanat of the accredited envoys to a given country," without constituting "an integral part of official international practices of states in the furtherance of their mutual relations." Id. at 770.

4. See, e.g., Dart, Why One Muslim's 'Jihad' is not Seen by All as 'Holy War', Los Angeles Times, Sept. 22, 1990, at F16 (explaining that the Arabic word "jihad" is often mistranslated as "holy war," when, in fact, "in Islam, the word holy applies only to Allah. And the word jihad (literally 'striving') primarily describes spiritual and intellectual efforts to become better Muslims and to spread the faith through peaceful means. . . '); see Leroux, Arabs' Culture and Language Help Shape Crisis in Middle East, 
between the main antagonists, Arabic-speaking Iraq and the Englishspeaking United States, has thrown the spotlight on legal issues relating to the use of language like few events in recent times. A review of several incidents that occurred during the crisis raises troubling questions about the chance of miscommunication in international relations and the primitive state of international law regarding language usage.

\section{Language in the Gulf Crisis}

\section{Linguistic Equality in International Law}

In past centuries diplomacy and communication between States were conducted by means of a common diplomatic language, most

Chicago Tribune, Aug. 19, 1990, at 12 (quoting interview with Prof. M. Cherif Bassiouni):

The word 'no' in English means 'no'. . . . But in Arabic, 'no' has a range of meanings including 'yes'. When a host offers a guest some coffee and sweets, the guest is expected to refuse so the host can insist. The language is less blunt than English or even French, and the language of Arab politics is especially flowery and ambiguous, full of possibilities for a dignified retreat.

The action of Iraq against Kuwait was almost universally called tadakhol, an act of intervention, rather than oudwan, an act of aggression. With tadakhol, there is no stigma, no name-calling. The subtleties of the language allow Arabs to voluntarily drift out of a position they may seem to have held.

See also MacNeil/Lehrer Newshour, Nov. 23, 1990, Friday Transcript \#3909 (hereinafter MacNeil/Lehrer) (quoting interview with Queen Noor of Jordan):

When the Arab point of view is expressed, or when there is an attempt at negotiating or communicating ideas with other cultures and particularly we're seen them in recent weeks with Western cultures over issues that are as emotional and vital, important to the welfare of the Arab community as well as to our relations to the West, I think that we've had a great deal of miscommunication or communication that's been out of synch.

It's [Arabic] a much richer language. It's a language that is used in a much more poetic and rhetorical, flowery fashion than English, which tends to perhaps reflect very well today a much more Western, businesslike, direct, definite approach to issues. It is not a language that is, has yetwe haven't yet developed the means to accommodate or synchronize it to the sound byte, if you will. And seeing as that was the mechanism by which so much of the dialogue has been carried out, I think there are many misunderstandings and many mistakes and many problems and that exacerbation of confusion and of fear and anxiety and emotions on both sides that led to an escalation of the crisis on all levels.

See also Said, Embargoed Literature, The Nation, No. 8, Sept. 17, 1990, at 278 (asking "is it too much to connect the stark political and military polarization with the cultural abyss that exists between Arabs and the West?"); see also A. Bozeman, The Future of Law in a Multicultural World 25-26 (1971) (regarding the difficulties of translation from Arabic); TABORY, supra note 1, at 88. 
prominently Latin, Castilian Spanish, or French. ${ }^{5}$ French eventually gained the upper hand and remained the predominant language of diplomacy until English was granted the status of an official language at the 1919 Paris Peace Conference. ${ }^{6}$ But while States still use diplomatic languages such as English or French a great deal in their relations,' international law now recognizes that the doctrine of State equality ${ }^{8}$ entitles a State to communicate in its own language (referred to here as the "rule of linguistic equality"). ${ }^{9}$ This rule seems to be based mainly on nationalism, ${ }^{10}$ perhaps given added impetus by decolonization and resultant pressures toward cultural diversity in the international system. ${ }^{11}$

5. TABORY, supra note 1 , at 4-5.

6. Id. at 5 .

7. Ajulo, Law, Language and International Organisation in Africa: The Case of ECOWAS, 29 J. African L. 1, 16-17 (1985) [hereinafter Ajulo]; see also Pitamic,

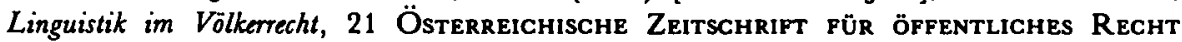
305, 305 (1971) [hereinafter Pitamic]; Satow's Guide to Diplomatic Practice 40 (Lord Gore-Booth ed. 1979) [hereinafter SATOw] (stating that "there is no universal rule making obligatory the use of one language rather than another and practice varies.").

8. The UN General Assembly has resolved that sovereign equality is an essential right of all States. Declaration on Principles of International Law concerning Friendly Relations and Co-operation among States in Accordance with the Charter of the United Nations, G.A. Res. 2625, 25 U.N. GAOR Supp. (No. 28) at 121, U.N. Doc. A/ 8082 (1970). Sovereign equality has been called "the linchpin of the whole body of international legal standards, the fundamental premise on which all international relations rest." A. Cassese, International Law in a Divided World 129-30 (1986).

9. Hilf, supra note 3 , at $27 ; 2$ OstroWer, supra note 3, at 73; SATow, supra note 7 , at 40 (stating that the "right of the representative of every nation to use the official language of that nation is now generally accepted"); A. Seren,, III Diritto intemazionale 1318-19 (1962); 2 K. STRUPP, Wörterbuch des VölKerRechts UNd DER Diplomatie 570 (1925); Ajulo, supra note 7, at 16; Pitamic, supra note 7, at 305 . See, e.g., Kempster, The Bush Letler: Aziz Refused to Touch the Sealed Envelope, Los Anceles Times, Jan. 11, 1991, at A7. Describing meetings in Geneva between Iraqi Foreign Minister Tariq Aziz and Secretary of State James Baker, the author notes that "although Aziz and several members of his delegation speak fluent English, the talks were conducted in both English and Arabic, using consecutive translation, which required each statement to be recited in full in the other language."

10. See, e.g., TABORY, supra note 1 , at 39 (noting in relation to the use of languages in the United Nations system that "the intense chauvinism of individual nations in favoring their own language even in procedural, nonsubstantive matters, such as the choice of language used to determine the alphabetical order of delegations, is illustrated by numerous instances.").

11. Id. at 46: "Third world nations in particular emphasize the notion of universality in international organizations, and insist that the diversity of the peoples represented must be taken into account." See also T. Franck, The Power of Lecitimacy 
The problem with the rule of linguistic equality is that it sanctions a diplomatic Babel; there is evidence, for example, that the proliferation of languages in the United Nations system has been a source of friction and confusion. ${ }^{12}$ During the Gulf Crisis, Iraq attempted to expand the rule even further when President Saddam Hussein alleged that the outrage over Iraq's use of Westerners as "human shields" was caused by misunderstanding of an Arabic word:

We in our communique used the word dar in Arabic, which means to put away or to prevent or to avoid the scourge of war or the injure [sic] of war. We used the word dar ${ }^{c}$, which means in Arabic to prevent, but when we used this word, Western media used - misunderstood the pronunciation of the word dar into dar which means "shield". And they thought that we were using people as a dar ${ }^{\circ}$, which means "shield", rather than as a darc, which we meant, which means to prevent war. So there was perhaps a deliberate misinterpretation of our wording of the communique. ${ }^{13}$

This argument must obviously be rejected; though confusion over translations may indeed give rise to honest misunderstandings, ${ }^{14}$ that

Among Nations 116 (1990) [hereinafter Franck]:

Understandably. . .it is the weaker states which most value the symbols of equality. . . . Less privileged nations believe that ritual incantation of their symbolically validated status as sovereign equals at least narrows the options of the powerful when they are tempted to take advantage of their military and economic pre-eminence.

12. TАBORY, supra note 1 , at 47 :

Indeed, through the proliferation of official and working languages, the United Nations, which was intended as a forum for greater understanding, has become perhaps more representative of the true state of the world, where people talk at each other in their own language, rather than with each other through a common language.

An example of a misunderstanding caused by the use of Arabic in the $\mathrm{UN}$ is described id. at 89-90.

13. MacNeil/Lehrer, supra note 4. The two Arabic words, which were transliterated as "derr" and derr respectively in the quoted passage, have been corrected to dar' and dar.

14. See, e.g., Sciolino, U.S. Says It Has Tape of Arafat Threat, N.Y. Times, Jan. 19, 1989, at A12. In early 1989 the State Department threatened to break off talks with Palestinian leader Yasir Arafat following a speech he gave in Arabic which, according to a translation made by the U.S. embassy in Riyadh, contained the following threat: "Whoever thinks of stopping the intifada before it achieves its goals, I will give him ten bullets in the chest." However, Arafat denied that any threat was made, 
Iraq is entitled to express itself in Arabic does not mean that the legality of its actions is judged by the linguistic meaning of the Arabic word it uses to describe them, ${ }^{15}$ especially when violations of basic human rights are involved. ${ }^{16}$ However, the present emphasis on linguistic equality may encourage disregard of the fact that the right of a State to express itself in its own tongue does not allow it to remove its actions from scrutiny under international law.

\section{Use (and Nonuse) of Translators}

There appear to be virtually no rules regulating the use of interpreters and language specialists ${ }^{17}$ in international relations. Since their use is controlled by diplomatic practice rather than international law, ${ }^{18}$ States are free to make any arrangements they please concerning language interpretation, ${ }^{19}$ such as using translators provided by other States. As has occurred in the past, ${ }^{20}$ the United States government was dependent on a translation provided by a foreign State when it had to evaluate the Iraqi proposal to withdraw from Kuwait after the war had begun in mid-February:

and a Kuwaiti newspaper provided the following, considerably more benign, translation of the passage: "Nobody can stop the uprising, and any Palestinian leader who calls for stopping it will expose himself to our people's bullets." Id.

15. See Meron, Prisoners of War, Civilians and Diplomats in the Gulf Crisis, 85 Ам. J. INT'L L. 104, 105 (1991) [hereinafter Meron] (stating that applicability of the Fourth Geneva Convention to civilians in Kuwait is not determined by "how Iraq characterizes the invasion" of Kuwait.).

16. See id. at 107 on the detention of foreign hostages by Iraq as a violation of international human rights law.

17. While strictly speaking an interpreter is "one who translates orally from one language to another" (American Heritage Dictionary of the English Language 685 (1969)), in this article the terms "interpreter" and "translator" will be used synonymously to signify one who expresses a thought in another language while retaining the original sense.

18. 1 Ostrower, supra note 3, at 516; see supra note 3 (regarding the distinction between international law and diplomatic practice).

19. 1 Ostrower, supra note 3 , at 520-526 (regarding differences in the use of language specialists in the American, British, and French diplomatic services).

20. See, e.g., P. Simon, The Tongue-Tied American 59-60 (1980) [hereinafter Simon) (quoting N.Y. Times, Feb. 2, 1979, at A24). A meeting between Chinese leader Teng Hsiao-ping and President Carter at the White House would not have been possible without the presence of a Harvard-educated interpreter from the Chinese Foreign Ministry, since "the United States Government. . does not employ anyone fully-qualified as a simultaneous interpreter from English to Chinese." Simon goes on to state that "we have no qualified translators for most of the world's languages in the United States government, an incredible commentary." Id. 
His [President Bush's] doubts were confirmed a short time later by Prince Bandar ibn Sultan, Saudi Arabia's ambassador to the United States, who sources said translated the Arabic document into English for the President and his top aides over the telephone.

The White House had awakened Bandar about 7 a.m. (EST) with news of the Iraqi proposal. About 30 minutes later, King Fahd and the Saudi minister of information [sic] telephoned their embassy here saying they had a copy of the Iraqi proposal.

There followed an extraordinary scene in which the minister of information read the document, with all its conditions, to Bandar in Arabic on one telephone, while the ambassador used a second telephone to translate it for Bush and his aides, including National Security Adviser Brent Scowcroft and his deputy, Robert M. Gates. ${ }^{21}$

It is disturbing when a State involved in a military conflict, especially a leading power such as the United States, ${ }^{22}$ is either unable or unwilling to translate communications from the enemy. Reliance on translations provided by a foreign State, even one as close an ally as Saudi Arabia was to the United States in the Gulf Crisis, not only implies a less than whole-hearted commitment to the peaceful resolution of the crisis, ${ }^{23}$ but also suggests a failure to appreciate the fact that translation errors can give rise to serious misunderstandings, ${ }^{24}$ and

21. Nelson, Bush Waging Personal War, Associates Reveal, Los Angeles Times, Feb. 17, 1991, at A1.

22. See Reisman, Some Lessons from Iraq: International Law and Democratic Politics, 16 YALE J. INT'L L. 203, 205 (1991): “The system of world order, as conceived in the United Nations Charter, continues to depend centrally on the United States."

23. It is noteworthy that "[ $t]$ he White House steadfastly rejected Iraqi calls for a negotiated end to the Persian Gulf Crisis." Weston, Security Council Resolution 678 and Persian Gulf Decision Making: Precarious Legitimacy, 85 AM. J. INT'L L. 516, 531 n.90 (1991) [hereinafter Weston].

24. See, e.g., Simon, supra note 20, at 8-9: "When President Jimmy Carter visited Poland, the world guffawed at the translation errors. President Carter's wish to 'learn your opinions and understand your desires for the future' came out 'I desire the Poles carnally."' See also Grossfeld, Language and the Law, 50 J. AIR L. \& CoM. 793 (1985) (regarding the difficulties of legal translation); see also Sacco, Legal Formants: A Dynamic Approach to Comparative Law (pt. 1), 39 AM. J. Coмp. L. 1, 20 (1991): "The complexity of the problems involved in legal translation makes the carelessness with which they are approached seem incredible"; Schroth, Legal Translation, 34 AM. J. Comp. L. Supp. 47 (1986). 
presents the risk that the foreign State may color the translation to suit its own interests. Finally, communications from a military opponent must often be evaluated quickly, and it may not always be possible to call on another State to supply translations on short notice. ${ }^{25}$

\section{Provocative Rhetoric in a Crisis}

States involved in a military confrontation often engage in provocative rhetoric which, if sufficiently virulent, may rise to the level of war-mongering, ${ }^{26}$ subversive, ${ }^{27}$ or defamatory propaganda, ${ }^{28}$ all of which are prohibited under international law. The period from the invasion of Kuwait to the commencement of military action by the allies was characterized by intense rhetoric on both sides. ${ }^{29}$ The United States government made several statements that seemed to skirt the edge of the permissible under international law, including comments by President Bush that the United States would welcome the ouster of President Saddam Hussein, ${ }^{30}$ and that Hussein was in certain ways

25. An example in a different context is described by Simon, supra note 20, at 41-42, quoting in part Washington Star, Feb. 18, 1979:

The kidnappers of U.S. Ambassador to Afghanistan Adolph Dubs took him to the Kabul Hotel. Before the tragic slaying, so the Washington Star reports: '[U.S.] Embassy officials had a brief chance to seize the initiative because they reached the hotel before Afghan police. But no one in the American party spoke fluent Dari or Pushtu, the two most widely used Afghan languages, or fluent Russian.

26. "War-mongering propaganda is propaganda calculated to implant in the minds of peoples a disposition or desire to engage in an international armed conflict." a. Larson \& J. Whitton, Propaganda: Towards Disarmament in the War of WORDS 62 (1964) [hereinafter LARSON \& WHITTON]; "[s]uch propaganda is a violation of international law." Id. at 82.

27. "Subversive propaganda consists of communications calculated to overthrow the existing internal political order of a state." Id. at 83 . "As to subversive propaganda, there is an impressive degree of consensus among the sources of international law establishing the illegality of such propaganda.' Id. at 103.

28. "Defamatory propaganda consists of those communications which tend to degrade, revile, and insult foreign states, or their institutions, leaders or agents, especially when such attacks are of a nature as to disturb peaceful relations between the states concerned." Id. at 104. "Defamatory propaganda by one state against another is generally considered to be a violation of international law." Id. at $\mathbf{1 1 0 .}$

29. MacNeil/Lehrer, supra note 4 (remarks of Charlayne Hunter-Gault): "Since the beginning of the crisis back in August, there's been no lack of strong public rhetoric on both sides."

30. See, e.g., Hundley, Egypt Sends Troops to Aid Saudis, Chicago Tribune, Aug. 12, 1990 1, 12. President Bush stated to reporters when asked about the possibility of Hussein's overthrow "that sometimes happens when leaders get so out of touch 
worse than Hitler. ${ }^{31}$ Calling for the overthrow of President Hussein might be regarded as war-mongering or subversive propaganda, while the Hitler analogy could constitute "name-calling whose object is to incite a foreign people against its leader," 32 and thus defamatory propaganda. Ironically, the Hitler analogy is unlikely to have had the same degree of resonance in the Middle East as it had in the United States. ${ }^{33}$

For their part, the Iraqis were hardly models of rhetorical restraint, especially given the poor quality of their translations into English. For example, the speech to the American people by President Hussein carried on television on September 25, 1990, which was delivered in Arabic with English subtitles provided by an Iraqi translator, ${ }^{34}$ contained passages such as the following:

with reality that they commit their country to outrageous acts." Asked later if the United States would support such a move, the President stated:

No, we're not prepared to support the overthrow. But I hope that these actions that have been taken (to boycott Iraq) result in an Iraq that is prepared to live peacefully in the community of nations. And if that means that Saddam Hussein changes his spots, so be it. And if he doesn't, I hope the Iraqi people do something about it so that their leader will live by the norms of international behavior that will be acceptable to other nations.

31. See Press Conference with President Bush, Federal News Service, Nov. 1, 1990. In response to a question asking how Saddam Hussein's actions compared with those of Hitler, President Bush replied:

Worse than that. . . I I mean, that is outrageous, but I think brutalizing young kids in a square in Kuwait is outrageous, too. And I think if you go back and look at what happened when the Death's Head Regiments went into Poland, you'll find an awful similarity. I was told, and we've got to check this carefully, that Hitler did not stake people out against military targets and that he did indeed respect-not much else-but he did indeed respect the legitimacy of the embassies. So we've got some differences here, but I'm talking-when I'm talking about-there-I see many similarities, incidentally.

32. LARSON \& WhitTon, supta note 26, at 104.

33. See MacNeil/Lehrer, supra note 4 (quoting interview with Thomas Friedman of the New York Times):

Hitler, of course, was a very ambiguous figure in Arab history. . not because he was a mass murderer, but because he was opposing the British and French for that matter. And so at a time when these people were occupied by the British and French, they-you know-they looked up to him. So the whole image just doesn't work in the Arab world. It doesn't resonate the same way it's been resonating with an American audience.

34. Carman, Saddam's Show on CNN a Fizzler, San Francisco Chronicle, Sept. 27 , 1990 , at E1. 
When a sow of vitality sets foot upon the moon of perfidy, it is with moral judgment of the God-fearing faithful legion that the cradle of God's messenger is reached in the hearts of resiliences and will be repelled through good example in the path of misguidances and cursed 'til the day of judgment. ${ }^{35}$

While this excerpt may be little more than gibberish, the presence of the flowery imagery characteristic of Arab politics ${ }^{36}$ indicates that President Hussein was trying to impress the American people with the same type of rhetoric he was accustomed to using successfully in the Middle East, ${ }^{37}$ just as President Bush probably would have expected his analogy to Hitler to be as powerful to a Middle Eastern audience as to a Western one.

Strong arguments could be advanced that the statements made by Presidents Bush and Hussein did not violate international law. Warmongering propaganda does not apply to "preparing people for use of force when under the United Nations Charter the use of force is a legitimate one," 38 and it is widely held that Security Council Resolution $678^{39}$ provided such authorization. ${ }^{40}$ Subversive propaganda is illegal only in peacetime ${ }^{41}$ and it seems that the period of military buildup which preceded the attack to free Kuwait should be characterized not as peace, but as a "gray zone between peace and war."42 Fair comment on a State's violations of its obligations under international law, such

35. Id.

36. Post, Don't Misjudge Saddam, Christian Science Monitor, Jan. 9, 1991, at 18: "Defiant rhetoric has been a hallmark of this conflict and lends itself to misinterpretation. The Arab world places great stock on expressive language and the very act of expressing brave resolve against the enemy."

37. MacNeil/Lehrer, supra note 4 (remarks of journalist Hisham Melham): “ $[\mathrm{H}] \mathrm{e}$ 's [Saddam Hussein] not necessarily only talking to you in the West-but he's also talking to his people. He is playing on his own cultural and metaphorical devices that are understood by the average Iraqi or the average Arab."

38. LARson \& WhitTon, supra note 26 , at 65.

39. S.C. Res. 678 (Nov. 29, 1990), 29 I.L.M. 1565 (1990).

40. Schachter, United Nations Law in the Gulf Conflict, 85 AM. J. INT'L L. 452 , 459 (1991): "As of January 16, Resolution 678 was treated as the legal basis of the large-scale military action by the coalition of states that brought about the defeat of Iraq. . . ."; see Weston, supra note 23 (criticizing Resolution 678 as a legal basis for the use of force).

41. LARSON \& WhitTon, supra note 26 , at 95.

42. See Meron, supra note 15 , at 106-07. Given that war is apt to be the natural result of such propaganda, it could be argued that the existence of such a "gray zone" should not affect its illegality. See Larson \& WhItTon, supra note 26 , at 83. 
as the Iraqi invasion of Kuwait, ${ }^{43}$ does not constitute defamatory propaganda. ${ }^{44}$

Nevertheless, the rhetoric of the United States and Iraq, even if it was not strictly illegal under international law, remains a cause for concern. The use of comparisons with Hitler and warlike imagery derived from Islam indicates that each leader was relying on symbols that would likely inflame public opinion in his own country, but which were culturally unintelligible to his opponent, and therefore were unlikely to have any effect on the crisis other than escalating the level of tension. Though the United States and Iraq were not engaged in direct negotiations in the period leading up to the war, ${ }^{45}$ it could be argued that their leaders still had a duty under international law not to make statements which would frustrate a peaceful resolution of the crisis. ${ }^{46}$

\section{Conclusions}

The incidents discussed above are evidence of a communications gap which existed between Iraq and the United States during the Gulf Crisis. While there is no evidence that they were the "cause" of the crisis, or that had the United States and Iraq spoken the same language and understood each other perfectly the war would not have occurred, this is not really the issue. Linguistic differences have only rarely been the direct cause of wars, ${ }^{47}$ but do tend to disrupt communication between States even under normal circumstances. ${ }^{48}$ If international disputes are

43. Weston, supra note 23 , at 517 n.3 for a listing of the various Security Council resolutions condemning Iraqi breaches of international law.

44. LARson \& WhitTon, supra note 26, at 118: "If a given state has violated its treaty obligations, or has transgressed an accepted norm of customary international law, other states are entitled to enter a protest or express their disapproval."

45. States negotiating with each other have an obligation to conduct themselves so that the negotiations are meaningful. North Sea Continental Shelf Cases (W. Ger. v. Den., W. Ger. v. Neth.), 1969 I.C.J. 4, 47.

46. UN Charter art. 2, para. 3: "All members shall settle their international disputes by peaceful means in such a manner that intemational peace and security, and justice, are not endangered" (emphasis added).

47. One example was the first Italian-Ethiopian war, which was precipitated by a discrepancy between the Italian and Amharic texts of the Treaty of Uccialli. TABORY, supra note 1, at 5; I LA PRASSI ItAliana di DiritTo INTERNAzIONALE 153-57 (2nd series 1979).

48. 2 Ostrower, supre note 3 , at 808 ; see also Processes of International Negotiations Project, International Negotiation: Analysis, Approaches, Issues 48 (V. Kremenyuk. ed. 1991): "Cultural differences, of which communication and language patterns are part, may be considered a central issue in international nego- 
to be settled peacefully, as they must be according to international law, ${ }^{49}$ and if "war between large groups is as much a problem of philosophy and language as of politics and economics," 30 then any instance in which communication between antagonists on the brink of a military confrontation is needlessly complicated because of a language gap is a cause for concern. That there are so few rules of international law dealing with the very means by which disputes are to be peacefully resolved, namely language, cannot be justified on the basis that State equality allows each State to cling fast to its own language practices; as has been noted in another context, it is "much too late to put forward a view of sovereignty which involves the assertion that it is a matter for each State's discretion whether or not it has a certain right." 51 Modifying the doctrine of linguistic equality in order to further the peaceful resolution of disputes need not undermine State equality as a fundamental principle of international law..$^{52}$

The fact that more detailed rules regarding language usage in the settlement of international disputes do not already exist does not mean that there are no sources from which they could be derived. For instance, principles set forth in multilateral treaties could give rise to new rules of customary international law more consistent with international stability. ${ }^{53}$ There is currently a trend toward codification of international

tiations"; see also L. Rangarajan, The Limitation of Conflict: A Theory of Bargaining and Negotiation 64-65 (1985):

The problem of loss of information in transmission is relevant to international negotiation because negotiators from different countries speak different languages. . . . Linguistic difficulties sometimes produce insuperable political problems.

49. U.N. Charter art. 2, para. 3; art. 33.

50. Q. Wright, A Study of War 1448 (2d ed. 1965).

51. F.A. MANN, The Doctrine of Jurisdiction in International Law, 111 RECuEIL DES Cours 9, 17 (1964).

52. 2 Ostrower, supra note 3 , at 745 :

Even if the use of a national language in official intercourse constitutes a recognized right and an exclusive prerogative of a state as an attribute of sovereignty, no reason can be advanced why states may not agree on certain linguistic practices or why the law may not regulate such usages.

See Franck, supra note 11 , at 114 :

Most informed observers of the international system understand. . .that the notion of sovereign equality must be taken cum grano salis: its meaning being restricted to such a degree of sovereignty and equality as is commensurate with the international system's objectives of peace, human survival, and socio-economic development.

53. R. Baxter, Treaties and Custom, 129 Recueil des Cours 25, 57, 73 (1971): 
legal standards for the peaceful resolution of disputes between States, and these efforts can provide a framework for the development of norms designed to prevent language-related misunderstandings. One such instrument is the Report of the Conference on Security and Co-Operation in Europe (CSCE) Meeting of Experts on Peaceful Settlement of Disputes, ${ }^{54}$ adopted at Valletta on February 8, 1991. The CSCE Report, which was drafted by the representatives of thirty-three States, ${ }^{55}$ sets forth the following principles for dispute settlement which might be of significance for the development of rules regarding linguistic practices: that recourse to a settlement procedure "is not incompatible with the sovereign equality of States"; ${ }^{56}$ that the participating States will develop "mechanisms designed to prevent disputes from occurring"; $; 7$ that they will take care "not to let any dispute among them develop in such a way that it will endanger international peace and security"; $; 8$ that they will "refrain throughout the course of a dispute from any action which may aggravate the situation"; 59 that they will make arrangements "enabling the maintenance of good relations"; ${ }^{60}$ that disputes should be settled "in good faith"; ${ }^{61}$ and that the participating States will "consider whether or not there is an appropriate role for a third party." 62

Another significant instrument is the recently-released United Nations Draft Handbook on the Peaceful Settlement of Disputes between States. ${ }^{63}$ While the Draft Handbook states that it is "descriptive in

"Treaties that do not purport to be declaratory of customary international law at the time that they enter into force may nevertheless with the passage of time pass into customary international law" if the relevant norms are "taken up by non-parties in such a way that State practice is 'extensive and virtually uniform"'; see Restatement (Third) of the Foreign Relations Law of the United States $\$ 102(3)$ (1987).

54. 30 I.L.M. 382 (1991).

55. Austria, Belgium, Bulgaria, Canada, Cyprus, the Czech and Slovak Federal Republic, Denmark, Finland, France, Germany, Greece, the Holy See, Hungary, Iceland, Italy, Liechtenstein, Luxembourg-the European Community, Malta, Monaco, the Netherlands, Norway, Poland, Portugal, Romania, San Marino, Spain, Sweden, Switzerland, Turkey, the USSR, the United Kingdom, the United States, and Yugoslavia. Id. at 384 .

56. Id. at 387 .

57. Id.

58. Id.

59. Id. at 388 .

60. Id.

61. Id.

62. Id. at 389 .

63. U.N. Doc. A/AC.182/L.68 (1990) [hereinafter Draft Handbook]; see 30 I.L.M. 261 (1990) for a description of the Draft Handbook. 
nature, is not a legal instrument, and does not commit States in any way," 64 it is of great value in discerning contemporary practice relating to dispute resolution. Among the principles recognized in the Draft Handbook are that States must settle disputes peacefully in such a manner that international peace and security are not endangered; ${ }^{65}$ that international disputes must be settled on the basis of the sovereign equality of States, ${ }^{66}$ but that use of a freely-agreed settlement procedure is not incompatible with this principle; ${ }^{67}$ that dispute settlement is governed by the principle of "good faith";"68 and that States are obligated to conduct negotiations in a meaningful fashion and in a spirit of cooperation. ${ }^{69}$

Rules of international law relating to language practices could be developed out of the principles delineated above. For instance, the concept of good faith could include a duty to maintain a staff of competent interpreters and translators; the obligation to solve disputes in a manner that will not endanger international peace and security could contemplate a reasonable effort to deal with linguistic and cultural differences, and to refrain from bellicose rhetoric in a time of crisis; and the restrictions placed on the sovereign equality of States could force States to recognize that their right to use their own languages is not unlimited, and does not excuse reliance on sophistic linguistic distinctions to frustrate the resolution of a dispute. If it is objected that a concept such as good faith is too vague to serve as a basis for more specific obligations, it should be remembered that the function of this principle in international law has been described as:

[c]omparable to that of a catalyst in a chemical reaction. Alone, the catalyst is completely passive. It must be added to other elements for a reaction to occur; without it, nothing will happen, even if all the necessary components are present in sufficient quantities. It is a bit the same with good faith. It is never taken into consideration by law in the abstract, as a purely psychological disposition. It is always related to specific behavior or declarations and it invests them with legal significance and legal effects. ${ }^{70}$

64. Draft Handbook, supra note 63 , at 12.

65. Id. at 14 .

66. Id. at 16 .

67. Id. at 18 .

68. Id. at 17 .

69. Id. at 27-29.

70. Virally, Good Faith in Public Intemational Law, 77 Am. J. INT'L L. 130, 133 34 (1983) (reviewing E. Zoller, La Bonne Foi en Droit International Public (1977)). 
Indeed, neither of the treaties described above would be of much practical value if the obligations they contain were not susceptible to serving as the source for more specific rules integral to dispute settlement. Taking these suggestions as a starting point for the progressive development of international law, States could begin to implement language practices which, over time, might crystallize into principles of customary international law. ${ }^{71}$

Since the development of customary law is likely to be a laborious process, in the interim resort could be made to the institution of "good offices" to prevent language-related misunderstandings. ${ }^{72}$ While at one time good offices referred to a process of dispute resolution with specific rules derived from treaties and customary international law, ${ }^{73}$ the term is now defined more broadly to include all actions "which aim, in some way or another, at bridging the gap in international controversies, at smoothing out difficulties resulting therefrom, at peacefully settling differences or at least at alleviating conflicts and, in a more general sense, at helping to maintain peace among nations." 74 This can include the provision of technical assistance to the parties, ${ }^{75}$ which could be

71. 2 Ostrower, supra note 3, at 808-09: “Linguistic usages, like any other international practices, may harden into customary rules of law through continued, uninterrupted practice." See, e.g., SATow, supra note 7, at 38-41 for a description of how this process occurred with respect to the doctrine of State equality in language usage; see also 2 Ostrower, supra, at 807:

As in other international situations in which interest of particular states has given way to that of the community of states, so also has there been a change in the general attitude regarding international linguistic practices. ... The adoption of language rules and procedures by various international organizations - the League of Nations, the United Nations, the international courts and tribunals-are [sic] also suggestive of the new official attitude toward the development of general linguistic rules for the mutual benefit of all states.

72. See Draft Handbook, supra note 63 , at $45-54$ for a review of good offices as a method of resolving international disputes.

73. See R. Probst, "Good Offices" in International Relations in the Light of Swiss Practice and Experience, 201 RecueIl des Cours 211, 225 (1988) [hereinafter Probst].

74. Id. at 235 .

75. See Bindschedler, Good Offices, in 1 Encyclopedia of Public International LAw 67, 67 (1981) [hereinafter BindscheDLER]: "Technical good offices include inviting the parties to conferences, convening and organizing such conferences as host State, making the necessary facilities available, organizing transport and communication, providing security arrangements and possibly finances. . . "' For example, Switzerland provided "the necessary means of communication and information" to Algeria in 1962 while using its good offices to resolve the dispute between Algeria and France during meetings in Geneva. Probsr, supra note 73, at 263. 
interpreted to mean the provision of translation services by an impartial third party in a crisis. ${ }^{76}$ Use of neutral language services would be preferable to States relying on their allies for them, ${ }^{77}$ and objections based on nationalism could be answered by pointing out that use of good offices is fully compatible with State sovereignty. ${ }^{78}$

An obvious candidate for the provision of such services through the good offices procedure would be the Secretary General of the United Nations. The UN has accumulated great experience in the interpretation between languages, ${ }^{79}$ and the Secretary General has used his good offices to resolve international conflicts on a number of occasions. ${ }^{80}$ While it is not known whether the UN has provided language services in the past to States involved in a crisis, it is settled that "the SecretaryGeneral can avail himself of the specialized services of other United Nations institutions whose participation is likely to reinforce the potential and strengthen the resources of his good offices," 81 which seems to contemplate this possibility. Providing language services would be a

76. Draft HandBook, supra note 63 , at 45-46 (stating that one of the purposes of good offices is to provide a channel of communication between the parties); see Probst, supra note 73, at 362 (finding that the present trend is to define good offices liberally as any action by a third party which can promote better understanding between States).

77. After the Storm, Newsweek, Mar. 11, 1991, at 26 (for an example of how reliance on allied States for translation assistance may lead to miscommunication in a crisis situation). The author states that conciliatory messages from Iraqi Foreign Minister Tariq Aziz near the end of the war

[1]ost clarity because the destruction of Iraq's infrastructure required the communications to pass through Soviet hands on their way to the United Nations. Aziz's first letter was written in Arabic, translated into Russian and then into English. When the Americans showed it to an Iraqi delegate at the United Nations, he had it translated back into Arabic and found that its meaning had been warped, as if in some giddy parlor game.

Id. While Iraq may have relied on the Soviet Union out of necessity rather than choice, this situation could have been avoided had Iraq been able to relay its messages directly to the United Nations.

78. See Bindschedler, supra note 75, at 67; Probst, supra note 73, at 256.

79. See TABORY, supra note 1 , at 71-90 for a description of language services in the United Nations.

80. See V. Pechota, The Quiet Approach: A Study of the Good Offices Exercised by the United Nations Secretary-General in the Cause of Peace 79 (1972): "The legitimacy of the Secretary General's good offices as a means of settling disputes peacefully within the meaning of Article 33 of the Charter has been clearly established."

81. Id. at 70 . 
promising method of reducing tensions in a crisis, ${ }^{82}$ and would have been particularly appropriate in the Gulf Crisis since a Security Council Resolution called on the Secretary General to "make available his good offices" to reach a peaceful solution to the conflict. ${ }^{83}$

Whatever specific means are chosen, one of the lessons of the Gulf Crisis is that current principles of international law relating to communication between States with different languages and cultures are insufficient to cope with the ever-increasing enthusiasm for the peaceful resolution of international disputes. However, sufficient bases exist upon which to construct more detailed rules that can minimize the effect of linguistic differences in the international community.

82. Id. at 81 :

The possibility of mobilizing all the resources of the United Nations is bound to strengthen the mediatory potential of the Secretary-General's good offices, particularly in situations which require for their solution expertise and administrative skills that are non-partisan and truly international in character.

See BindsCHEDler, supra note 75, at 68: "Technical good offices have the most favourable chances of success because here political considerations recede into the background."

83. S.C. Res. 674 (Oct. 29, 1990), 29 I.L.M. 1563 (1990); see Nanda, The Iraqi Invasion of Kuwait: The U.N. Response, 15 S. ILL. U. L.J. 431, 441, 451 (1991), (for an account of the Secretary General's fruitless efforts to use his good offices to resolve the conflict). 